1

41

42

\title{
The Use/Abuse of Oral Contraceptive Pills Among Males: A Mixed-Method Explanatory Sequential Study Over Jordanian Community Pharmacists
}

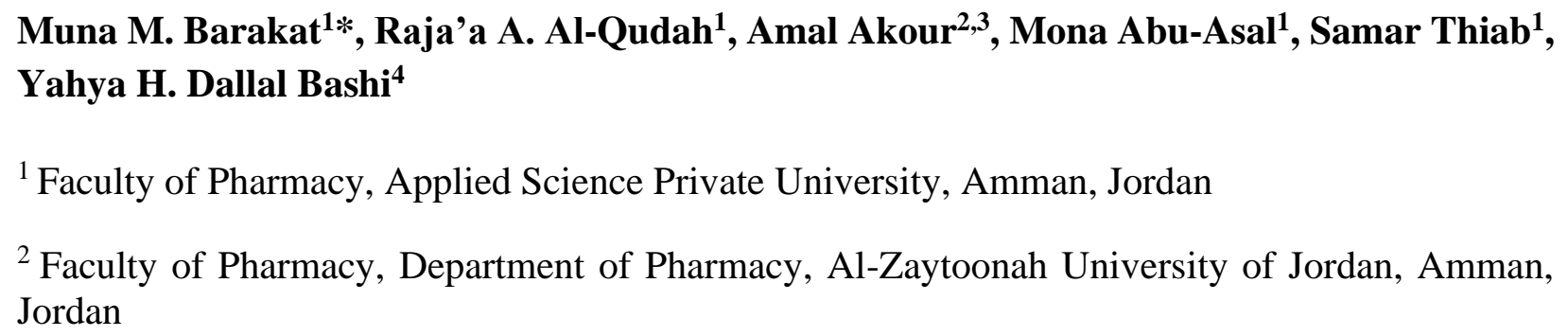

${ }^{3}$ School of Pharmacy, Department of Biopharmaceutics and Clinical Pharmacy, The University of Jordan, Amman, Jordan

${ }^{4}$ School of Pharmacy, Queen's University Belfast, BT9 7BL, UK

\section{*Corresponding author:}

Muna Barakat, Faculty of Pharmacy

Applied Science Private University, Amman, Jordan.

Phone number: +962 797348180

Email: $\underline{\text { m_barakat@asu.edu.jo }}$ 


\section{Abstract}

Background: Oral contraceptive pills (OCPs) are considered one of the most important birth control methods in the world. However, these pills were designed for female administration rather than males. This study was designed to investigate patterns of OCPs use and abuse among Jordanian males, according to the community pharmacists' observations.

Method: A mixed-method explanatory sequential study was conducted using an online selfadministered survey and semi-structured in-depth interviews for community pharmacists. The

51 interviews were utilized using a conceptual framework. Inductive thematic analysis and descriptive/regression analyses were completed using Nvivo and SPSS, respectively.

Results: A total of 158 questionnaire responses and 22 interviews were included in our analysis. Around half (48.4\%) of the questionnaire responses confirmed that males could use OCPs for hair growth enhancement, muscle gain and acne treatment $12.7 \%, 31.7 \%$ and $4.4 \%$, respectively. Through the interviews, the majority of the pharmacists highlighted that most of the males use OCPs for bodybuilding purposes, according to recommendations by their coaches at the gym. The most abused OCPs containing estrogen (Ethinyl estradiol) and progestins (Drospirenone or

59 Levonorgestrel).

Conclusion: This study provided insight into unexpected uses of OCPs by males in Jordan.

61 Community pharmacists have a crucial role in the management of OCPs use and abuse, However, restricted regulations and monitoring must be released and implemented on the community to limit such practices.

64 Keywords: Abuse; community pharmacists; Jordan; males; oral contraceptive pills; OCPs. 


\section{Introduction}

The non-therapeutic consumption of medications, in terms of abuse and misuse, is recently on the rise. Medication abuse is defined as the usage of drugs for non-medical purposes [1]. The most common medications which are prone to abuse are products containing opioids, stimulants and laxatives [2-4]. However, the abuse of oral contraceptive pills (OCPs) has not been fully examined yet.

OCPs are one of the most common birth control methods in the United States (US), mainly used by females between the ages of 25-44 years old [5]. There are three types of OCPs: combined estrogen-progesterone, progesterone alone and continuous dosing or extended cycle pills [6]. It was reported that the combined oral contraceptive (COC) pills were the most prescribed compared with the other types [6]. The main indication for these pills is pregnancy control; however, the Food and Drug Association (FDA) labeled additional uses for them such as menstrual period

81 disorders (Dysmenorrhea, amenorrhea, oligomenorrhea), acne treatment, hirsutism, polycystic

82 ovary syndrome and many other uses [7]. OCP's labeled indications are generally approved for

83 females rather than males. The frequent use of OCPs among males may contribute to adverse

84 physiological effects such as gynecomastia, testicle shrinkage, prostate cancer and diminished 85 libido [8].

In Jordan, it was reported that OCPs are the second most common birth control method [9, 10],

87 and OCPs are sold over the counter [9]. Such unsupervised practice could be associated with 88 inappropriate administration of many medications [11] including OCPs, as reported by the 89 Jordanian community pharmacist in a previous study [12]. In that study, pharmacists stated that 90 both genders are prone to OCPs improper usage, such as topical application of OCPs for hair 91 growth enhancement and OCPs were used to give a false negative result for an addictive drug 
medRxiv preprint doi: https://doi.org/10.1101/2021.03.11.21253403; this version posted March 12, 2021. The copyright holder for this preprint (which was not certified by peer review) is the author/funder, who has granted medRxiv a license to display the preprint in perpetuity.

All rights reserved. No reuse allowed without permission.

screening test [12]. Therefore, this study aims to investigate the patterns of OCPs use and abuse among Jordanian males, according to the community pharmacists' observations.

\section{Method}

A mixed-method explanatory sequential (qualitative and quantitative) study was conducted in order to understand the pharmacist observations about patterns of OCPs use/abuse among Jordanian males. The first phase of the study, which was conducted from March $15^{\text {th }}$ to April $24^{\text {th, }}$ 2020, consisted of a self-administered online survey, targeting Jordanian community pharmacists and pharmacy trainees. Pharmacists were recruited through social media platforms (Facebook, WhatsApp, LinkedIn, and Twitter). The second phase of the study, which was carried out from April $25^{\text {th }}$ to May $15^{\text {th }}, 2020$, consisted of online semi-structured in-depth interviews, using Zoom®, with maximum variation purposive sample of community pharmacists. The study was approved by the Institutional Review Board of Applied Science Private University [Ethical approval number: 2019-PHA-14]. The sequential method is represented in Figure 1.

\subsection{Quantitative method (first phase)}

An online self-administered survey has been developed and validated (face and content validity) by clinical researchers to solicit anonymous responses, which were treated confidentially. The survey has been developed using the general principles of good survey design [13]. The surveys contain closed-ended and open-ended questions that are completed within an average of 7 minutes. The survey had been administered in Arabic and English via Google ${ }^{\circledR}$ forms technology. Participants were also clarified that their participation in the study was voluntary and did not pose any risks. Potential participants who completed the survey were considered to have given informed consent for the study participation. 
117 The first draft of the survey was appraised by 20 independent academic staff members who have 118 decent experience in oral contraceptives research studies; as well a statistician was consulted at this stage of validation. The final version of the survey was refined according to the provided comments and feedback, translated from English into Arabic and then was back-translated by two

121 specialized academics. The questions were free from medical jargon or difficult terminologies.

122 The final validation stage was the piloting step, which involved 25 academic and 25 non-academic 123 participants. This stage of the study was conducted to enhance clarity, readability, 124 understandability, and confirm the study applicability in the Jordanian community pharmacists. 125 Internal consistency reliability was tested by the Cronbach's alpha coefficient $(=0.82)$.

126 The study survey included three parts. The first part (Part A) comprised nine questions including 127 sociodemographic information; the second part (Part B) consisted of four questions comprising 128 details of knowledge and beliefs of pharmacists about OCPs uses for males. The questions of 129 knowledge were mainly concerned about the presence of possible indications for OCPs in males and the risks of using those pills. The last part (Part C) was focusing on the pharmacist experience

131 and practice towards OCPs usage by males; which consisted of ten multiple-choice questions.

132 Based on Tabachnick and Fidell recommendation for sample size calculation in linear regression 133 analysis, 5-20 subjects per predictor are suggested to be preferable [14]. Based on the number of 134 independent variables levels used in this study $(n=9)$ and using the number of 10 subjects per 135 predictor level, a minimum sample size of 90 or higher was considered suitable for the purpose of 136 this study.

137 In this study, the recruited sample was 162 community pharmacists who met the inclusion criteria. 138 The eligibility criteria for participation are being Jordanian pharmacists and trainees (who were working/training in community pharmacy). Sample-sized recruitment was conducted using a 
medRxiv preprint doi: https://doi.org/10.1101/2021.03.11.21253403; this version posted March 12, 2021. The copyright holder for this preprint (which was not certified by peer review) is the author/funder, who has granted medRxiv a license to display the preprint in perpetuity.

All rights reserved. No reuse allowed without permission.

140

141

142

143

144

145

146

147

148

149

150

151

152

153

154

155

156

157

158

159

160

161

convenience sampling method. The inclusion criteria were explained at the start of the survey, which stated: "If you are working or training at a community pharmacy, please let us know if you would like to participate in this survey".

\subsection{Statistical analyses}

The data of the completed surveys were extracted from an electronic platform and exported to Statistical Package for Social Sciences version 24.0 (SPSS® Inc., Chicago, IL, USA) for the statistical analysis. Descriptive statistics included percentages, means, and frequency distribution, calculated for each question. Descriptive and univariate correlation analyses using Pearson correlation coefficient ( $r$ ) were used for the correlation, which was conducted at a 5\% significance level. A $p$-value of $<0.05$ represented a significant difference. Factors affecting the OCPs' improper uses were analyzed using simple and multivariate linear regression.

\subsection{Qualitative Method (Second Phase)}

The qualitative study was conducted using semi-structured in-depth interviews for community pharmacists. The sample was recruited purposively then maximum variation sampling was conducted, to reach sample saturation (22 community pharmacists). Purposeful sampling directed the researcher to find community pharmacists with pure experiences regarding OCPs usage among males. In this regard, introductory pilot interviews were employed to find the pharmacists who provide fruitful and detailed responses then the selected pharmacists participated in in-depth interviews.

A series of questions regarding the use of OCPs among males were asked and answered freely by the participants. This research instrument was reviewed by a group of leading clinical pharmacy researchers to ensure the suitability of the measurement tool. The interview included three probing questions. The first was "From your experience, please describe how could males use the OCPs", 
164 and the second was "What is the best way to limit the abuse of OCPs among males?", each 165 interview lasted for 25 minutes. The participants were informed that all the data will be treated 166 confidentially and signed electronic informed consents. The interviews were recorded and

167 transcribed verbatim. Transcripts were written in Arabic (the native language of Jordan), translated 168 into English, checked for clarity and accuracy, uploaded to NVivo12 (qualitative data analysis

169 software; QSR International Pty Ltd. Version 12) for coding and then analyzed using inductive 170 thematic analysis using conceptual framework methods [15]. The inter-rater reliability was 171 assessed using Cohen's kappa. The kappa value for the three coders was 0.85, indicating good 172 agreement between the coders. The different researchers independently re-checked the 173 trustworthiness and the accuracy of transcription, translation and inter-coder reliability.

\section{Results} phases

179 Out of the total 162 completed questionnaires (response rate $=98 \%$ ), four forms $(2.4 \%)$ were excluded from the study due to incomplete responses, accordingly, 158 (97.5\%) questionnaires were included in the analysis. The majority of the participating pharmacists were females $(\mathrm{n}=118$,

$18274.2 \%)$ and around half of them $(n=79,49.7 \%)$ were <40 years old and holding both university education degrees (bachelor's and postgraduates) $(n=111,70.2 \%)$.

184 About half of the pharmacists $(n=75,47.5 \%)$ have been working in community pharmacies for 185 more than 10 years, which is located in the capital of Jordan "Amman" $(n=115,72.3 \%)$. Around $18674 \%(\mathrm{n}=117)$ of the pharmacy's customers were classified as middle social class, from the 
medRxiv preprint doi: https://doi.org/10.1101/2021.03.11.21253403; this version posted March 12, 2021. The copyright holder for this preprint (which was not certified by peer review) is the author/funder, who has granted medRxiv a license to display the preprint in perpetuity.

All rights reserved. No reuse allowed without permission.

187 pharmacists' perception. It is worth noting that $44.7 \%(\mathrm{n}=71)$ of the pharmacies were adjacent to 188 sports gyms (Table 1).

189 The sociodemographic data of the qualitative phase was representing the maximum variation 190 sample. A total of 22 pharmacists were involved in the study. Females percentage was slightly 191 predominant over males $(n=12,54.5 \%)$, less than one third were $41-55$ years old $(n=7,31.8 \%)$ and $192(\mathrm{n}=17,77.3 \%)$ were holding a bachelor's degree (Table 1).

\subsection{Knowledge and beliefs of pharmacists about male's usage of OCPs}

195 The majority of the participants $(n=77,48.4 \%)$ agreed that OCPs could be used by males. The 196 pharmacists reported that males could use OCPs for muscle gain purposes, enhancement of hair 197 growth and acne treatment in $31.7 \%, 12.7 \%$ and $4.4 \%$, respectively. Pharmacists' knowledge about 198 possible OCPs side effects, when used by males, was assessed. The most reported side effects were 199 gynecomastia, decreased libido, mood changes, and increased body weight $(69.8 \%, 64.8 \% 64.8 \%$, $20057.9 \%$ ) respectively (Table 2).

201

\subsection{Pharmacist experience and practice towards OCPs usage by males} prescription, and around 58\% of them were dispensing OCPs for males for their personal use. In particular, for muscle gain $(36.5 \%)$ and hair growth enhancement $(20.8 \%)$. Some of the participating pharmacists also indicated that most males who used to use OCPs were stranger customers $(n=43,27.7 \%)$ and most commonly aged 20-35 $(n=114,71.7 \%)$. Study participants 
medRxiv preprint doi: https://doi.org/10.1101/2021.03.11.21253403; this version posted March 12, 2021. The copyright holder for this preprint (which was not certified by peer review) is the author/funder, who has granted medRxiv a license to display the preprint in perpetuity.

All rights reserved. No reuse allowed without permission.

209

210

211

212

213

214

215

216

217

218

219

220

221

222

223

224

225

226

227

228

229

230

231

recognized by their facial expression and body language, $21.5 \%$ and $27.2 \%$, respectively (Table 3).

Multivariate logistic regression results exhibited a positive significant correlation $(p<0.05)$ between the pharmacist exposure to males OCPs abuse cases and the following variables: age of the pharmacist, female gender, the length of pharmacist experience (in years), the relatively low social class distribution of the pharmacy customers, Table 4.

\subsection{Qualitative phases results:}

\section{Theme 1: The most common patterns of OCPs abuse among males}

Pharmacists confirmed that most of the male OCPs users were 22-35 years old. The majority of the participants highlighted that most of the males use OCPs for bodybuilding purposes, according to recommendations by their coaches at the gym. They also reported that the presence of a gym facility around the pharmacy increases the potential to observe such cases. All male customers were asking for OCPs containing estrogen (Ethinyl estradiol) and progestins (Drospirenone or Levonorgestrel). Participant 4 declared that "After a period of 3 months, the same customers came to the pharmacy asking for Tamoxifen (selective estrogen receptor modulator) or Clomiphene citrate tablets (nonsteroidal, ovulatory stimulant), claiming that this will clear their bodies from the side effects of OCPs". All the participants confirmed that there is general use for hormonal products among gyms, including OCPs and testosterone.

Thirty percent of the participating pharmacists said some of the customers came to their pharmacy asking for OCPs for drug-addiction-related issues. Participant 5 stated, "most commonly, cocaine abusers came to ask for OCPs approximately five hours before their annual urine test of illicit drugs in order to give a negative result". Participant 7 also mentioned that "some customers 
medRxiv preprint doi: https://doi.org/10.1101/2021.03.11.21253403; this version posted March 12, 2021. The copyright holder for this preprint (which was not certified by peer review) is the author/funder, who has granted medRxiv a license to display the preprint in perpetuity.

All rights reserved. No reuse allowed without permission.

232

233

234

235

236

237

238

239

240

241

242

243

244

245

246

247

248

249

250

251

252

253

254

usually asking for eye drops containing Naphazoline $\mathrm{HCl}$ and Chlorpheniramine Maleate to manage their eye symptoms due to addiction".

On the other hand, the pharmacists indicated that males use OCPs for hair growth purposes. Participant 10 said, "As the men's beauty centers recommend males to grind OCPs and mix them with shampoo for topical application to improve their hair growth". Participant 13 acknowledged "Such practice is more common in the presence of beauty centers around the pharmacy". As well, fifty percent of the participants stated that beauty centers also recommend topical application of OCPs (grinded pills mixed with topical products) for acne treatment.

\section{Theme 2: The role of pharmacist and pharmacy policymakers in the management of OCPs}

\section{abuse among males}

Most of the participants said that they could distinguish the abusers of OCPs by their facial impressions and body language/shape, as well as frequent visits to the pharmacy asking for the same products and even sometimes the customer explicitly clarify his need. Additionally, all participants agreed on the importance of the pharmacist role to fight the abuse of OCPs and came up with some recommendations such as“'Once I know that there is any misuse for OCPs, I would advise the customer to avoid this practice and mention the side effects (especially the risk for impotence) for him," said participant 20. In addition, they advocated the conduction of awareness campaigns, videos and distribution of pamphlets to increase knowledge and awareness about the proper use of OCPs, especially for gyms and beauty centers. Finally, the participant emphasized that pharmacists should report the abuse or misuse cases to the policymakers such as the Jordanian Pharmacist Association (JPA) and pharmacovigilance committee in the Jordan Food and drug association (JFDA) to monitor such practice. 


\section{Discussion}

257 The abuse of body performance- or appearance- enhancing drugs by males has been increasing all 258 over the world [16, 17], as well as in the Middle Eastern countries [17], which mostly include 259 androgens [17, 18] and growth hormones [19]. However, the abuse of OCPs for these 260 aforementioned purposes has never been reported in the literature. In the current study, community 261 pharmacists were able to identify and report unanticipated patterns of OCPs use among Jordanian 262 males, which provides an insight into the pharmacists' role in patient education to limit medication 263 abuse.

264 Half of the pharmacists participating in this study were aware of the possibility of OCPs use by 265 males for body appearance enhancing purposes such as muscle augmenting, hair growth as well as an acne treatment. They were also knowledgeable about the side effects of OCPS in males, such

267 as gynecomastia, mood changes, altered libido, and weight gain. These side effects were actually 268 similar to those reported in a recent study that evaluated hormonal contraception for men [20]. 269 Most males buying OCPs were young (25-35 year old), and this was comparable to other studies 270 that evaluated the abuse of androgenic steroids by male athletes in Jordan which found that the 271 mean age of the abusers was 28.1 years [21]. Tahtamouni [21] showed that in $42.9 \%$ of the abuse 272 cases, gym coaches were responsible for recommending medication use/abuse. Similar to our 273 study, participants also confirmed that the presence of a gym facility around the pharmacy 274 increases the potential to observe such cases. The accessibility and affordability of OCPs make 275 them more prone to misuse/abuse [22].

276 Although our findings demonstrated that around forty percent of the pharmacists refused to 277 dispense OCPs in cases of suspected improper use, yet the rest of them would agree to do so. 
medRxiv preprint doi: https://doi.org/10.1101/2021.03.11.21253403; this version posted March 12, 2021. The copyright holder for this preprint (which was not certified by peer review) is the author/funder, who has granted medRxiv a license to display the preprint in perpetuity.

All rights reserved. No reuse allowed without permission.

278 Unfortunately, community pharmacists in Jordan still dispensed OCPs without prescription, which

279 is contrary to the national regulations by the JPA or JFDA [23]. The lack of control over OCPs

280 prescribing will lead to the augmentation of the problem of improper OCPs use. Previous studies

281 showed that these practices can be attributed to the pressure on the community pharmacists to sell

282 the medication, due to financial considerations of the pharmacy owners, or the continuous push

283 from the pharmaceutical companies [24]. This issue is very important at the national as well as the

284 international level, hence, many studies have investigated the possibility of changing the status of

285 OCPs to be an over the counter medication and expanding the scope of pharmacists' practice

286 beyond counseling and education to prescribing [25-28]. This suggests that there is a need for strict

287 regulations and guidance to control any possibility of improper medication use. Still, our study

288 showed that those pharmacists who refused to dispense emphasized that pharmacists should report

289 the abuse or misuse cases to the policymakers such as the JPA and pharmacovigilance committee

290 in the JFDA to monitor such practice.

291 Remarkably, most of the documented cases of the improper use of OCPs in this study have been

292 rarely recognized in previous studies. Our qualitative analysis showed that OCPs were abused to

293 mask the results of addiction to drug urine tests. It was shown that several adulterants could be

294 added to urine in order to give a false-negative drug test, which could deter the ability to monitor

295 illicit drug use [29]. These can include oxidizing chemicals, such as nitrite or peroxide, as well as

296 non-oxidizing chemicals. Hajhashemi et al. (2007) conducted an in vitro and in vivo study

297 assessing the interaction of OCPs (ethinylestradiol, levonorgestrel (LN), and both of them) at a

298 high dose with a urine morphine diagnostic test, after reporting plenty of claims about this

299 issue[30]. The results of that study confirmed the absence of such an interaction, which strongly

300 suggests there is a need to stop misusing these medications. However, such practices are still 
available according to our study findings, which should highlight the need for further future studies to better understand this issue and devise suitable recommendations for policymakers. adverse effects [31]. Clomiphene is used in females to induce ovulation, and also has an off-label use for the treatment of hypogonadism [32, 33]. It has both estrogenic and antiestrogenic properties and initiates a series of endocrinologic events that eventually lead increase in steroidogenesis [33]. Still, the mechanism by which clomiphene can alleviate the adverse effects of OCPs is yet unclear. In this study, the reporting of OCPs abuse cases by males was correlated to many factors according to our study results, including the extent of the pharmacist's experience. Usually, the experience

312 in the pharmacy profession may strengthen the potential of the pharmacist to distinguish the cases 313 of proper/abuse use of medication [34]. Moreover, the low social class distribution of pharmacy 314 customers was one of the significantly affecting factors. The effect of socio-economic distribution 315 on substance use (e.g. illicit drugs and alcohol) was investigated in the literature, not about OCPs, 316 which reveals that "low social status report more environmental challenges and less psychosocial 317 resources and that this can lead to feelings of hopelessness and a loss of coping ability" [35]. This 318 could explain the abuse of OCPs by males to mask the urine test results of the illicit drug.

319 In Jordan, the policymakers and stakeholders (JFDA) emphasized that birth control pills should be 320 handled under prescription, and till the time of writing this study it is not allowed to handle such 321 medication as over-the-counter medications [36]. Nevertheless, a lack of surveillance and strict 322 control opens the chance to abuse the OCPs and make them accessible to the abusers, which could 
medRxiv preprint doi: https://doi.org/10.1101/2021.03.11.21253403; this version posted March 12, 2021. The copyright holder for this preprint (which was not certified by peer review) is the author/funder, who has granted medRxiv a license to display the preprint in perpetuity.

All rights reserved. No reuse allowed without permission.

323 ultimately lead to an increase of side effects and complications [37]. However, there is limited

324 documentation on cases of the use and abuse cases of OCPs among males.

325

326 5. Strengths and limitations

327 This has been the first study in Jordan to addresses various patterns of use/abuse of OCPs by males,

328 which are encountered in the community pharmacy setting. However, a number of limitations have

329 been raised. The first limitation of this study was the survey was conducted online due to the

330 COVID-19 pandemic that started around January of 2020 [38], along with the lockdown which

331 was enforced by the law (till mid-June 2020). Another limitation was the use of convenient non-

332 random sampling. Finally, this study had a small sample size (quantitative part), which might be

333 due unfamiliarity of the pharmacists about this issue.

\section{Conclusion}

336 This study provided insight into unexpected uses of OCPs by males in Jordan. Community

337 pharmacists have a crucial role in the management of OCPs use and abuse, However, restricted

338 regulations and monitoring must be released and implemented on the community to limit such

339 practices. These regulations should be highlighted by both policymakers and drug regulatory

340 institutions in Jordan. In addition, there is a deep need for national educational and awareness

341 programs for the Jordanian community about the safe and proper use of OCPs.

\section{Conflicts of Interest}

344 All authors declare that they have no conflict of interest.

\section{8. Funding}


This study was not funded by any institution.

\section{Availability of data and materials}

The data will be made available by the corresponding author upon request.

\section{References}

1. WHO. Abuse (drug, alcohol, chemical, substance or psychoactive substance) 2016. Available from: https://www.who.int/substance abuse/terminology/abuse/en/.

2. Ciccarone D. Stimulant abuse: pharmacology, cocaine, methamphetamine, treatment, attempts at pharmacotherapy. Primary Care: Clinics in Office Practice. 2011;38(1):41-58.

3. Fay JJ, Patterson D. Chapter 18 - Substance Abuse. In: Fay JJ, Patterson D, editors. Contemporary Security Management (Fourth Edition): Butterworth-Heinemann; 2018. p. 391-411.

4. Roerig JL, Steffen KJ, Mitchell JE, Zunker C. Laxative abuse. Drugs. 2010;70(12):1487-503.

5. Daniels K, Dougherty J, Jones J. Current contraceptive status among women aged 15-44: United States, 2011-2013: US Department of Health and Human Services, Centers for Disease Control and ...; 2014.

6. Cooper DB, Mahdy H. Oral contraceptive pills. 2019.

7. Schindler AE. Non-contraceptive benefits of oral hormonal contraceptives. International journal of endocrinology and metabolism. 2013;11(1):41-7. Epub 2012/12/21. doi: 10.5812/ijem.4158. PubMed PMID: 23853619.

8. Kirkpatrick K. What if a man takes birth control pills? 2015 [cited 2020]. Available from: https://science.howstuffworks.com/science-vs-myth/what-if/what-if-man-takes-birth-control-pills.htm.

9. Bardaweel SK, Akour AA, Kilani M-VZJBwsh. Current knowledge, attitude, and patterns of oral contraceptives utilization among women in Jordan. 2015;15(1):117.

10. Kridli S, Newton SJINR. Jordanian married Muslim women's intentions to use oral contraceptives. 2005;52(2):109-14.

11. Albsoul-Younes $A$, Wazaify $M$, Yousef $A-M$, Tahaineh LSu, misuse. Abuse and misuse of prescription and nonprescription drugs sold in community pharmacies in Jordan. 2010;45(9):1319-29.

12. Barakat $\mathrm{M}, \mathrm{Al}$-Qudah Ra, Akour A, Al-Qudah N, Dallal Bashi YH. Unforeseen uses of oral contraceptive pills: Exploratory study in Jordanian community pharmacies. PLOS ONE. 2020;15(12):e0244373. doi: 10.1371/journal.pone.0244373.

13. Boynton PM, Greenhalgh T. Selecting, designing, and developing your questionnaire. Bmj. 2004;328(7451):1312-5.

14. Tabachnick BG, Fidell LS, Ullman JB. Using multivariate statistics: Pearson Boston, MA; 2007.

15. Bahr SJ, Hoffmann JPJThod, society. Social scientific theories of drug use, abuse, and addiction. 2016:197-217.

16. Kanayama G, Pope HG, Jr. Illicit use of androgens and other hormones: recent advances. (17522978 (Electronic)).

17. Sagoe D, Pallesen S. Androgen abuse epidemiology. Current opinion in endocrinology, diabetes, and obesity. 2018;25(3):185-94. doi: 10.1097/MED.0000000000000403. PubMed PMID: 29369917.

18. Handelsman DJ. Use, Misuse, and Abuse of Androgens. In: Simoni M, Huhtaniemi IT, editors. Endocrinology of the Testis and Male Reproduction. Cham: Springer International Publishing; 2017. p. 1251-85. 
medRxiv preprint doi: https://doi.org/10.1101/2021.03.11.21253403; this version posted March 12, 2021. The copyright holder for this preprint (which was not certified by peer review) is the author/funder, who has granted medRxiv a license to display the preprint in perpetuity.

All rights reserved. No reuse allowed without permission.

19. Brennan BP, Kanayama G, Hudson JI, Pope HG, Jr. Human growth hormone abuse in male weightlifters. The American journal on addictions. 2011;20(1):9-13. doi: 10.1111/j.15210391.2010.00093.x. PubMed PMID: 21175915; PubMed Central PMCID: PMC3104052.

20. Thirumalai A, Ceponis J, Amory JK, Swerdloff R, Surampudi V, Liu PY, et al. Effects of 28 Days of Oral Dimethandrolone Undecanoate in Healthy Men: A Prototype Male Pill. The Journal of clinical endocrinology and metabolism. 2019;104(2):423-32. doi: 10.1210/jc.2018-01452. PubMed PMID: 30252061; PubMed Central PMCID: PMC6306388.

21. Tahtamouni LH, Mustafa NH, Alfaouri AA, Hassan IM, Abdalla MY, Yasin SR. Prevalence and risk factors for anabolic-androgenic steroid abuse among Jordanian collegiate students and athletes. European journal of public health. 2008;18(6):661-5. doi: 10.1093/eurpub/ckn062. PubMed PMID: 18603598.

22. Bardaweel SK, Akour AA, Al-Muhaissen S, AlSalamat HA, Ammar K. Oral contraceptive and breast cancer: do benefits outweigh the risks? A case - control study from Jordan. BMC Womens Health. 2019;19(1):72. doi: 10.1186/s12905-019-0770-x. PubMed PMID: 31159800; PubMed Central PMCID: PMC6547482.

23. The United States Agency for International Development (USAID). Jordan Program Profile 2015 [cited 2020 24th August]. Available from: https://www.shopsplusproject.org/sites/default/files/resources/Jordan\%20Program\%20Profile final pri nt.pdf.

24. Mahmoud MA, Aldhaeefi M, Sheikh A, Aljadhey H. Community pharmacists perspectives about reasons behind antibiotics dispensing without prescription: a qualitative study. 2018.

25. Irwin AN, Stewart OC, Nguyen VQ, Bzowyckyj AS. Public perception of pharmacist-prescribed selfadministered non-emergency hormonal contraception: An analysis of online social discourse. Res Social Adm Pharm. 2019;15(6):650-5. doi: 10.1016/j.sapharm.2018.08.003. PubMed PMID: 30143467.

26. Rafie S, Richards E, Rafie S, Landau SC, Wilkinson TA. Pharmacist Outlooks on Prescribing Hormonal Contraception Following Statewide Scope of Practice Expansion. Pharmacy (Basel). 2019;7(3). doi: 10.3390/pharmacy7030096. PubMed PMID: 31323818; PubMed Central PMCID: PMC6789671.

27. Kennedy CE, Yeh PT, Gonsalves L, Jafri H, Gaffield ME, Kiarie J, et al. Should oral contraceptive pills be available without a prescription? A systematic review of over-the-counter and pharmacy access availability. 2019;4(3):e001402.

28. McIntosh J, Rafie S, Wasik M, McBane S, Lodise NM, El-lbiary SY, et al. Changing oral contraceptives from prescription to over-the-counter status: an opinion statement of the Women's Health Practice and Research Network of the American College of Clinical Pharmacy. 2011;31(4):424-37.

29. Fu S. Adulterants in Urine Drug Testing. Adv Clin Chem. 2016;76:123-63. doi: 10.1016/bs.acc.2016.05.003. PubMed PMID: 27645818.

30. Hajhashemi V, Minaiyan $M$, Saberian-Boroojeni $M$. In vitro and in vivo interaction of oral contraceptive high dose (HD) with urine morphine diagnostic test. J Physiology and Pharmacology. 2007;11(1):68-75.

31. Tan RS, Vasudevan D. Use of clomiphene citrate to reverse premature andropause secondary to steroid abuse. (0015-0282 (Print)).

32. Soares AH, Horie NC, Chiang LAP, Caramelli B, Matheus MG, Campos AH, et al. Effects of clomiphene citrate on male obesity-associated hypogonadism: a randomized, double-blind, placebocontrolled study. International journal of obesity. 2018;42(5):953-63. doi: 10.1038/s41366-018-0105-2. PubMed PMID: 29777228.

33. Herzog BJ, Nguyen HMT, Soubra A, Hellstrom WJG. Clomiphene Citrate for Male Hypogonadism and Infertility: An Updated Review. Androgens: Clinical Research and Therapeutics. 2020;1(1):62-9. doi: 10.1089/andro.2020.0005. 
medRxiv preprint doi: https://doi.org/10.1101/2021.03.11.21253403; this version posted March 12, 2021. The copyright holder for this preprint (which was not certified by peer review) is the author/funder, who has granted medRxiv a license to display the preprint in perpetuity.

All rights reserved. No reuse allowed without permission.

34. Ilardo ML, Speciale AJIJoER, Health P. The Community Pharmacist: Perceived Barriers and PatientCentered Care Communication. 2020;17(2):536.

35. Spooner C, Hetherington K. Social determinants of drug use: National Drug and Alcohol Research Centre, University of New South Wales ...; 2005.

36. Jordan, Food and Drug Administration (JFDA). List of Non-prescription medications 2018 [cited 2020 24th August]. Available from: http://www.jfda.jo/Pages/viewpage.aspx?pagelD=359.

37. Huang $Q, C$ hai $X$, Xiao $C, C a o X$. A case report of oral contraceptive misuse induced cerebral venous sinus thrombosis and dural arteriovenous fistula. Medicine (Baltimore). 2019;98(33):e16440. doi: 10.1097/MD.0000000000016440. PubMed PMID: 31415348; PubMed Central PMCID: PMC6831267.

38. Lai C-C, Shih T-P, Ko W-C, Tang H-J, Hsueh P-R. Severe acute respiratory syndrome coronavirus 2 (SARS-CoV-2) and corona virus disease-2019 (COVID-19): the epidemic and the challenges. International journal of antimicrobial agents. 2020:105924.
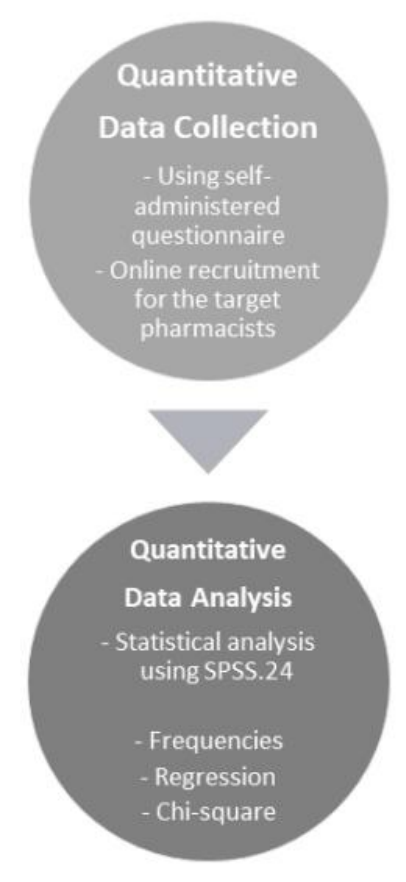

Figure 1. Descriptive scheme for the study mixed sequential method.
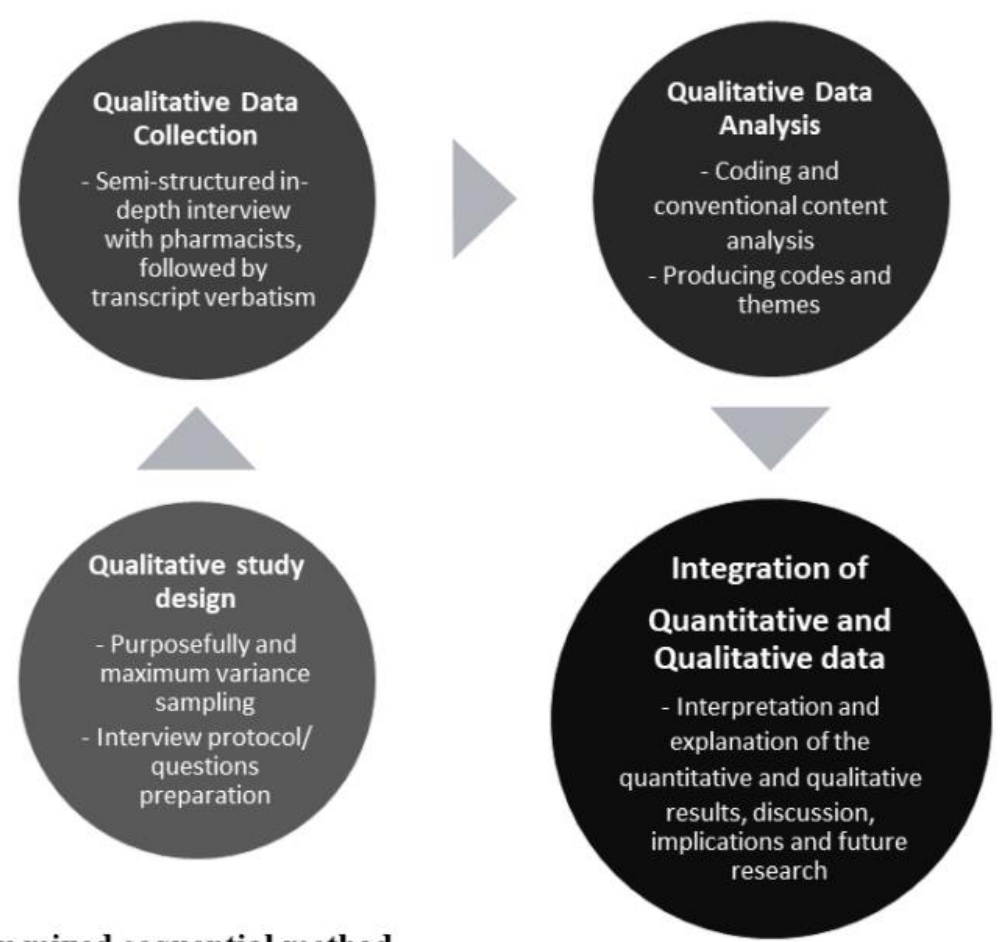
medRxiv preprint doi: https://doi.org/10.1101/2021.03.11.21253403; this version posted March 12, 2021. The copyright holder for this preprint (which was not certified by peer review) is the author/funder, who has granted medRxiv a license to display the preprint in perpetuity.

Table 1. Sociodemographic characteristics of the participants in both Quantitative $(n=158)$ and Qualitative phases $(\mathbf{n}=\mathbf{2 2})$.

\begin{tabular}{|c|c|c|}
\hline Characteristic & $\begin{array}{c}\text { Questionnaire Sample } \\
\text { n (\%) }\end{array}$ & $\begin{array}{c}\text { Interviews Sample } \\
\text { n }(\%)\end{array}$ \\
\hline \multicolumn{3}{|l|}{ Gender } \\
\hline - Female & $118(74.2)$ & $12(54.5)$ \\
\hline - Male & $41(25.8)$ & $10(45.5)$ \\
\hline \multicolumn{3}{|l|}{ Age (years) } \\
\hline - $20-25$ & $16(10.1)$ & $5(22.7)$ \\
\hline - $26-40$ & $79(49.7)$ & $5(22.7)$ \\
\hline - $41-55$ & $59(37.1)$ & $7(31.8)$ \\
\hline - $\quad>55$ & $5(3.1)$ & $5(22.7)$ \\
\hline \multicolumn{3}{|l|}{ Education } \\
\hline - Bachelor's degree & $100(63.3)$ & $17(77.3)$ \\
\hline - Pharmacy student + trained in a pharmacy & $35(22.2)$ & $4(18.2)$ \\
\hline - Postgraduate degree & $11(6.9)$ & $1(4.5)$ \\
\hline - Diploma & $12(7.5)$ & 0 \\
\hline \multicolumn{3}{|l|}{ Years of experience } \\
\hline - $<5$ & $35(22.2)$ & $4(18.2)$ \\
\hline - 5 to 10 & $48(30.4)$ & $4(18.2)$ \\
\hline - 11 to 15 & $58(36.7)$ & $5(22.7)$ \\
\hline - $16-20$ & $8(5.0)$ & $5(22.7)$ \\
\hline - $\quad>20$ & $9(5.7)$ & $4(18.2)$ \\
\hline \multicolumn{3}{|l|}{ Position in the pharmacy } \\
\hline - Employee pharmacist & $94(59.5)$ & $9(40.9)$ \\
\hline - Trainee in a pharmacy & $37(23.4)$ & $6(27.3)$ \\
\hline - Pharmacy owner & $27(17.6)$ & $7(31.8)$ \\
\hline \multicolumn{3}{|l|}{ Province where you work } \\
\hline - The capital of Jordan (Amman) & $115(72.3)$ & $13(59.1)$ \\
\hline - East of Jordan & $9(5.7)$ & $2(9.1)$ \\
\hline - West of Jordan & $6(3.8)$ & $3(13.6)$ \\
\hline - North of Jordan & $16(10.1)$ & $2(9.1)$ \\
\hline - South of Jordan & $1(0.6)$ & $2(9.1)$ \\
\hline \multicolumn{3}{|l|}{$\begin{array}{l}\text { The most common social class distribution } \\
\text { of the pharmacy customers }\end{array}$} \\
\hline - Low & $21(13.3)$ & $5(22.7)$ \\
\hline - Middle & $117(74.0)$ & $13(59.1)$ \\
\hline - High & $20(12.7)$ & $4(18.2)$ \\
\hline \multicolumn{3}{|l|}{ The presence of sport gym around the pharmacy } \\
\hline - Yes & $71(44.7)$ & $14(63.6)$ \\
\hline - $\quad$ No & $63(39.6)$ & $8(36.4)$ \\
\hline - Not sure & $24(15.1)$ & 0 \\
\hline
\end{tabular}


medRxiv preprint doi: https://doi.org/10.1101/2021.03.11.21253403; this version posted March 12, 2021. The copyright holder for this preprint (which was not certified by peer review) is the author/funder, who has granted medRxiv a license to display the preprint in perpetuity.

All rights reserved. No reuse allowed without permission.

Table 2. Pharmacists knowledge and beliefs about the possible uses of OCPs among males $(\mathbf{n}=158)$

\begin{tabular}{lcc}
\hline Question & n & \% \\
\hline According to your knowledge and opinion, could males use OCPs? & & \\
- Yes & 77 & 48.4 \\
- No & 52 & 32.7 \\
- Not sure & 29 & 18.2 \\
According to your knowledge and opinion, what are the possible uses of & & \\
OCPs for males? & & \\
- Enhancement of hair growth & 20 & 12.7 \\
- Muscle gain (bodybuilding) & 50 & 31.7 \\
- Acne Treatment & 7 & 4.4 \\
- No uses & 52 & 32.7 \\
- Other uses & 3 & 1.9 \\
- Not sure & 26 & 16.5 \\
Which of the following could be possible side effects of OCPs, if used by & & \\
males? (Yes/No) * & & \\
- Acne flare-up & 64 & 40.3 \\
- Altered libido & 103 & 64.8 \\
- Night sweats & 61 & 38.4 \\
- Mood changes & 103 & 64.8 \\
- Gynecomastia & 111 & 69.8 \\
- Suppression of high lipoprotein cholesterol (HDL) & 48 & 30.2 \\
- Reversible reduction in testicular volume & 64 & 40.3 \\
- Increased body weight & 92 & 57.9 \\
\hline
\end{tabular}

- The showed results represent the "Yes" answers. 
medRxiv preprint doi: https://doi.org/10.1101/2021.03.11.21253403; this version posted March 12, 2021. The copyright holder for this preprint

(which was not certified by peer review) is the author/funder, who has granted medRxiv a license to display the preprint in perpetuity.

All rights reserved. No reuse allowed without permission.

Table 3. pharmacist experience and practice towards OCPs usage by males $(n=158)$

\begin{tabular}{|c|c|c|}
\hline Question & $\mathbf{n}$ & $\%$ \\
\hline \multicolumn{3}{|c|}{$\begin{array}{l}\text { Have you ever dispensed OCP s in your pharmacy to males (for their } \\
\text { personal use) }\end{array}$} \\
\hline - Yes & 92 & 57.9 \\
\hline - $\quad$ No & 34 & 21.4 \\
\hline - I have never asked about the user & 32 & 20.8 \\
\hline \multicolumn{3}{|c|}{ Have you ever dispensed OCPs to males for the following uses? } \\
\hline - Enhancement for the hair growth & 32 & 20.8 \\
\hline - Muscle gain (bodybuilding) & 58 & 36.5 \\
\hline - Acne treatment & 2 & 1.3 \\
\hline - Never & 66 & 41.5 \\
\hline \multicolumn{3}{|c|}{ The most common ages of males came to the pharmacy asking for OCPs (years) } \\
\hline$\bullet \quad<20$ & 12 & 8.2 \\
\hline - $20-35$ & 114 & 71.7 \\
\hline - $36-50$ & 30 & 18.9 \\
\hline - $>50$ & 2 & 1.3 \\
\hline \multicolumn{3}{|c|}{ Have you ever noticed any inappropriate use of OCPs by males? } \\
\hline - Yes & 68 & 43.4 \\
\hline - No & 44 & 27.7 \\
\hline - Not sure & 46 & 28.9 \\
\hline \multicolumn{3}{|c|}{ What was the kind of OCPs' male customers in the last 3-6 months } \\
\hline - Known customers & 3 & 1.9 \\
\hline - Strangers & 43 & 27.0 \\
\hline - Known and strangers & 28 & 17.6 \\
\hline - Not sure & 84 & 52.8 \\
\hline \multicolumn{3}{|c|}{$\begin{array}{l}\text { How many males came to your pharmacy asking for OCPs in the last 3-6 } \\
\text { months }\end{array}$} \\
\hline$\bullet<5$ & 120 & 75.9 \\
\hline - $>5$ & 38 & 24.1 \\
\hline \multicolumn{3}{|c|}{ How could you recognize the males who use OCPs inappropriately } \\
\hline - From the facial impressions and body language & 43 & 27.2 \\
\hline - They admit their needs directly & 34 & 21.5 \\
\hline - Hard to recognize & 60 & 38.0 \\
\hline - All the options & 21 & 13.3 \\
\hline
\end{tabular}


Table 4. Summary of the linear regression analysis (single and multivariant) to assess predictors associated with the exposure of participating pharmacists to OCPs use among males.

\begin{tabular}{|c|c|c|c|c|}
\hline & Single Lin & gression & Multiva & it regression \\
\hline Independent factors & Beta & $p$-value & Beta & $p$-value \\
\hline Age & & & & \\
\hline - $\leq 40$ years & Reference & & & \\
\hline - $\quad>40$ years & 0.512 & 0.033 & 0.499 & 0.047 \\
\hline Gender & & & & \\
\hline - Female & Reference & & & \\
\hline - Male & -0.143 & 0.001 & -0.128 & $<0.001$ \\
\hline Education & & & & \\
\hline - $\geq$ University degree & Reference & & & \\
\hline - < University degree & 0.711 & 0.127 & ------- & -------- \\
\hline Years of experience & & & & \\
\hline - $\leq 10$ years & Reference & & & \\
\hline - $>10$ years & 0.349 & 0.003 & 0.325 & $<0.001$ \\
\hline Province of the work & & & & \\
\hline - The capital (Amman) & Reference & & & \\
\hline - Outside the capital & -0.473 & 0.275 & ------- & ------- \\
\hline Social class distribution of the & customers & & & \\
\hline - Low & Reference & & & \\
\hline - Moderate/high & -0.067 & 0.005 & -0.063 & $<0.001$ \\
\hline Presence of Sport Gym around & nacy & & & \\
\hline - Yes & Reference & & & \\
\hline - No & -0.352 & 0.052 & ------- & -------- \\
\hline
\end{tabular}

